\title{
Potential of Combustion of Poultry Litter for Space Heating in Poultry Production
}

\author{
Mogomotsi J. Molefe ${ }^{1} \&$ Isaac N. Simate ${ }^{1}$ \\ ${ }^{1}$ Department of Agricultural Engineering, University of Zambia, P.O. Box 32379, Lusaka, Zambia \\ Correspondence: Mogomotsi J. Molefe, Department of Agricultural Engineering, School of Engineering, \\ University of Zambia, Lusaka, Zambia. Tel: 267-75-043-374. E-mail: mogomotsimolefe@rocketmail.com
}

Received: March 9, 2019

Accepted: April 16, 2019

Online Published: May 30, 2019

doi:10.5539/eer.v9n1p29

URL: https://doi.org/10.5539/eer.v9n1p29

\begin{abstract}
Confined poultry production, which is expected to double by 2050, produces a lot of litter. For successful and sustainable poultry production, litter management is prompted and should be prioritized. Poultry litter can serve as an energy feedstock for space heating and electricity generation. Currently, heating systems in use depend on electricity, charcoal or diesel which are very expensive leading to high energy costs in poultry production. The purpose of this study was therefore to investigate the potential of combustion of poultry litter for space heating in poultry production. A brazier with 32 holes, of a diameter of $1 \mathrm{~cm}$, on its sides comprising of dimensions; Diameter $=8 \mathrm{~cm}$ and Height $=65 \mathrm{~cm}$ was used to burn $1 \mathrm{~kg}$ of Poultry Litter Briquettes. The briquettes were made with a mincer which had a nozzle of dimensions, Length $=11 \mathrm{~cm}$ and Diameter $=25 \mathrm{~mm}$ producing briquettes of a diameter of $25 \mathrm{~mm}$ and a length of $10 \mathrm{~cm}$. The briquettes were made from poultry litter of chickens at the ages of 4, 5 and 6 weeks, and were either sun or solar dried. They were then directly combusted in the brazier and heat distribution was measured at distances of $30 \mathrm{~cm}, 60 \mathrm{~cm}$ and $90 \mathrm{~cm}$ from the brazier. Charcoal was used as a control. The maximum average temperatures recorded on the surface of the brazier for week $4,5,6$ were $471^{\circ} \mathrm{C}, 491^{\circ} \mathrm{C}$, $493^{\circ} \mathrm{C}$ respectively; whereas for charcoal was $555^{\circ} \mathrm{C}$. However, the poultry litter briquettes were not able to sustain high temperatures for long compared to charcoal. Complete combustion took an average of 120 minutes while charcoal took an average of 180 minutes.
\end{abstract}

Keywords: poultry litter, poultry litter briquettes, direct combustion, heat distribution, calorific value

\section{Introduction}

Due to the limited availability and the carbon dioxide emissions of fossil fuels which cause global warming, heat and power generation through the combustion of biomass has become an issue of importance (Bogush et al., 2018). Direct combustion (DC) is mostly used in developing countries which according to Demirbas, (2004) is an ancient method of utilizing biomass, operational in over $97 \%$ of the world's bio-energy production. It involves the burning of a material in the presence of oxygen to produce thermal energy (Weidemann et al., 2015). Bird excreta combined with bedding material is defined as poultry litter (Butcher and Miles, 2015). Poultry litter (PL) comprises mainly the bedding material, feathers, manure and the spilt feed (Bolan et al., 2017). More than $93 \%$ of the population in rural areas of Zambia own indigenous Zambian chickens (Andrew, 2011). Samboko et al., (2016) reported annual estimations of layer and broiler production in 2014 to be 1,005,910,434 tons and 372,285,812.16 tons respectively. Poultry production results in hatchery wastes, manure, litter, and on-farm mortalities. The litter produced is normally used as an organic fertilizer but mismanagement of this practice can bring the risk of surface and groundwater contamination when it is over applied to soil (Kelleher et al., 2002) since Zambia has a high water table. Ammonia emissions disturb air quality and this is classified as the major pollutant to the environment in poultry production (Williams, 2008). When using litter as fuel rather than as fertilizer, environmental pollution can be reduced (Dalólio et al., 2017). Technologies have risen aimed towards safe disposal of poultry litter. Inclusive are technologies highlighted by Musa et al., (2012), like converting broiler and turkey litters into bio oils and generating a gas to operate a pyrolysis unit. Additionally, poultry litter is used for electric generation in a number of plants in the US and in the UK.

Space heating of poultry houses can be carried out through direct combustion of PL. However, increment in moisture content of the litter causes a decrease in its calorific value. Thyagarajan et al., (2013) reported that air dried samples have typical values of $13.5 \mathrm{GJ} /$ ton as their calorific value being about half that of coal. Temperature 
is one of the most significant environmental factors determining performance in poultry birds. Any deviation from the tolerated temperature range will trigger their thermoregulatory mechanisms for survival leading to negative consequences on their performance (Jini et al., 2015). The required temperature of any broiler house ranges from $22^{\circ} \mathrm{C}$ to $32^{\circ} \mathrm{C}$ depending on the birds' age (Zanaty, 2015). Provision of adequate heat is essential during brooding since chicks cannot survive without it (Nabangi, 2015). Currently, the heating systems in use depend on either electricity, charcoal or diesel which are very expensive. Using charcoal contributes to the high deforestation rate which stands at 250 000-300 000 hectares annually, placing Zambia among the top 10 countries with high deforestation rates worldwide (Matakala et al., 2015). Similarly, Tembo et al., (2015) highlighted that Zambia's forest covers approximately 49468000 hectares of the land but it is still among top 10 greenhouse gas emitting countries due to deforestation.

\section{Method}

This study was conducted at the University of Zambia; Latitude $15.3^{\circ} \mathrm{S}$; Longitude $28.3^{\circ} \mathrm{E}$. The University's Department of Agricultural Engineering workshop was used to run the experiments. Experiments were conducted in June and July (winter) for DC comparisons of Poultry Litter Briquettes (PLB) dried in a solar tunnel dryer (STD) and open sun drying (OSD) to those of a control experiment using charcoal. Sampling of poultry litter was from the university's poultry house at week 4,5 and 6 . The litter, which had a bedding of wood shavings, was collected from the broiler house which accommodated 3000 chickens. The collected litter was fresh and not subjected to any treatment. Charcoal was bought from the City Market. The first experimental procedure was that of making PLB preceding that of determination of initial moisture content of PLB. The calorific value of the briquettes was lastly determined from Zambia Bureau of Standards (ZABS).

\subsection{Making Briquettes}

After sampling, the collected poultry litter was hand crushed so that it could blend easily when mixed with the binder (cassava flour) and water. Cassava provides strength and combination efficiency to briquettes (Teixeira et al., 2010). The PL paste was prepared by adding cassava flour and water to PL in a bucket and mixed by hands until a homogenous mixture was formed. For PL sample at week 4, 800g of cassava flour was added to $1800 \mathrm{~g}$ of poultry litter and mixed with $2400 \mathrm{ml}$ of water. The feed-flour ratio was $44.44 \% .1800 \mathrm{~g}$ of PL at week 5 was mixed with $300 \mathrm{~g}$ of cassava flour and $1600 \mathrm{ml}$ of water. The feed-flour ratio at this age was $16.67 \%$. At week $6,250 \mathrm{~g}$ of cassava flour was mixed with $1800 \mathrm{~g}$ of PL and $1600 \mathrm{ml}$ of water and yielded a feed-flour ratio of $13.89 \%$. A research by Altun et al.,(2004) reported a ratio of 10\%, by weight of biomass, for both water and flour to be used. The same ratio was used in this research but resulted in a less coherent paste. Therefore, flour and water were added until a homogenous paste which could easily be molded was formed. Cassava is categorized as an organic binder. Organic binders have good bonding performance, high crush strength and drop test strength and decompose easily at high temperatures (Zhang et al., 2018).

\subsubsection{Densification of PL}

Before briquettes were made, the paste was allowed to settle for 15 minutes so that a uniformly compacted product could be produced. A stainless-steel hand mincer, primarily intended for sausage making, was used to make PL briquettes. A fabricated nozzle which was made of galvanized iron sheet was fitted in the mincer to serve as a die where PL briquettes were pressed through. The nozzle had a length of $11 \mathrm{~cm}$ and a diameter of $25 \mathrm{~mm}$. Since the paste was highly viscous, it was pressed into the feeding hopper by hand so that it could be pushed by the rotating worm through the die thus forming briquettes. The worm rotates as the handle is being rotated. Continual rotation of the worm acts as a pump causing compression at the far end of the barrel which consequently forces the paste through the die. A continuous briquette was formed which was measured to $10 \mathrm{~cm}$ by a ruler and cut using a knife. Hence briquettes formed had a length of $10 \mathrm{~cm}$ and a diameter of $25 \mathrm{~mm}$. The briquettes were then dried with the prior said methods. Figure 1 shows how PL briquettes were made. 


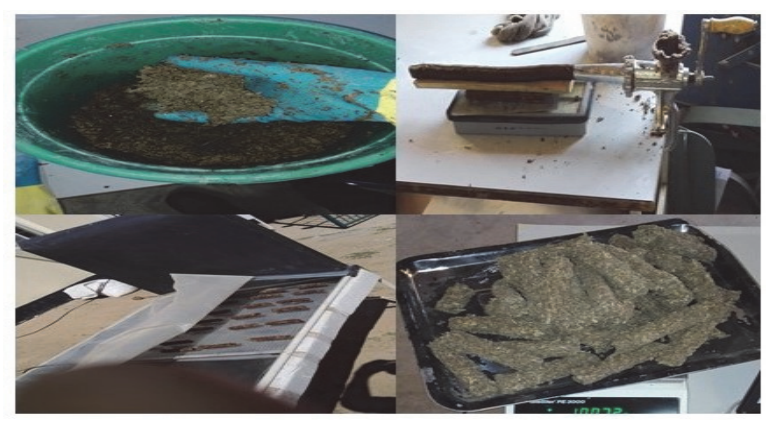

Figure 1. The process followed when PL briquettes were made

From Figure 1, poultry litter was mixed with the binder and water to make a paste which was moulded to briquettes and dried for combustion experiments.

\subsection{Determination of Moisture Content}

The initial moisture content of PLB was determined by oven drying (Jeio Tech, Model ON-02G, accuracy $\pm 0.5 \%$ ) at $70^{\circ} \mathrm{C}$. The samples were weighed at intervals of 30 minutes until there was no significant difference between successive weights. After determining the initial moisture content, the briquettes were either solar tunnel dried or open sun dried from an average moisture content of $61 \%(\mathrm{wb})$ to a final moisture content in a range of $0.2-11.2 \%$ (wb), (Molefe and Simate, 2019) and compared under DC as shown in Figure 2.

\subsection{Direct Combustion of Poultry Litter}

The dried samples from the solar dryer and open sun drying were directly combusted in the brazier which was first taken outside so that the smoke from the startup of burning could be released. It was left for a period of 30 minutes before each experiment was started. The initial temperature of the surface of the brazier was recorded. During direct combustion experiments, temperature measurements were taken at various positions from the brazier as shown in Figure 2.

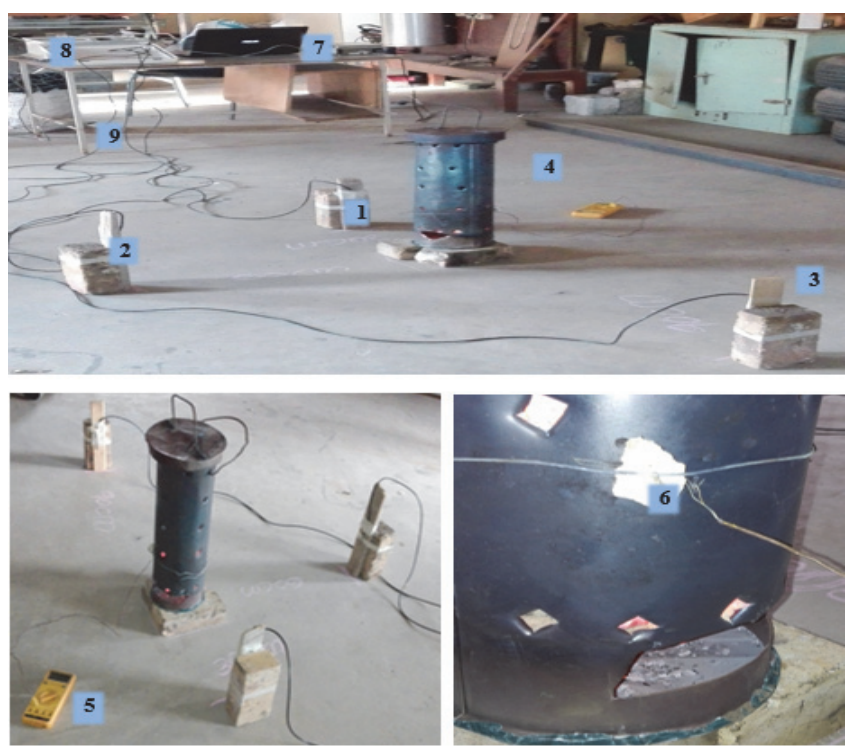

Figure 2. The side and top view of the experimental set up for the DC process throughout the experiment for all ages of PLB and charcoal

Thermocouple (1), (2) and (3) were placed at distances $30 \mathrm{~cm}, 60 \mathrm{~cm}$ and $90 \mathrm{~cm}$ from the brazier respectively. (4) a brazier with a lid, photo (5) a digital multimeter, (6) a high temperature probe tied on the surface of the brazier, (7) laptop connected to a data logger (8) and a humidity probe (9) which was used to measure ambient temperature.

One kg of PLB, weighed with a digital balance, from different weeks were each combusted in the brazier which had an average of 32 holes on its sides to allow for oxygen entrance during burning. It comprised of dimensions; 
Diameter $=8 \mathrm{~cm}$ and Height $=65 \mathrm{~cm}$. Two space-heating braziers of the same dimensions and made of the same material (mild steel) were bought from the City Market and were adopted for the application of the methodology of this study. They were used interchangeably to allow for cooling off for the next experimental step. For each experimental run, the brazier was covered with a lid so that the heat produced could not escape through the mouth. Heat distribution was measured at distances of $30 \mathrm{~cm}, 60 \mathrm{~cm}$ and $90 \mathrm{~cm}$ from the brazier. A high temperature digital multimeter (Dynatek 9030a) coupled with a temperature probe, (ANSI Code: Type K, accuracy $\pm 1.1^{\circ} \mathrm{C}$ or $\pm 0.4 \%$ ) with the capability of recording temperatures from $-270^{\circ} \mathrm{C}$ to $1300^{\circ} \mathrm{C}$, was used to record the brazier surface temperature as time lapsed at an interval of 10 minutes. A data logger, connected to a computer, was used to record the ambient temperature and air temperatures from the thermocouples as a result of the combustion of PLB. The experiments took place at different times of the day. Charcoal was combusted and used as a control. After DC, the ash from all the ages was weighed on a digital balance to determine the ash content of PLB according to weeks as well as that of charcoal. The following equation was used;

$$
\text { Ash Content }(\%)=\left(\frac{M_{\text {ash }}}{M_{\text {briquette }}}\right) * 100
$$

Where; $\mathrm{M}_{\text {ash }}$ is the weight of the ash, $\mathrm{M}_{\text {briquette }}$ is the weight of the dried PLB.

\subsection{Calorific Value (CV) Determination}

All fuels have a physical property termed CV defined as the amount of heat released during a combustion process which is regularly expressed in kilocalories or kilojoules of one $\mathrm{kg}$ or liter of fuel (Bouabid et al., 2015). The PLB samples were taken to ZABS for CV determination. An IKA C5003 calorimeter system was used for this experiment. The CV of PLB, was determined by the bomb calorimetric method according to standard test method for gross calorific value of coal and coke (D 5865-03). From the dried PLB, few samples were taken for CV experimentation. The dried sample was ground to powder where about 1 gram of it was weighed on an electronic balance and pelleted then placed in a crucible. A crucible with a pellet containing about 1 gram of PLB was inserted into the bomb. After closing the bomb, it was filled with oxygen (purity 99.99\%), (Acar and Ayanoglu, 2012), under a pressure of 3 bars. The bomb was placed in the calorimetric equipment filled with water and the sample was ignited electrically. The resulting increase of the water temperature allows the calculation of CV of the sample to be done. The heat capacity of the calorimeter was determined using benzoic acid pallets as a standardizing material. The $\mathrm{CV}$ of the sample was then calculated by multiplying the temperature rise in the calorimeter (water jacket) by the heat capacity of the calorimeter determined from benzoic acid.

\section{Results and Discussions}

\subsection{Moisture Content}

The moisture contents of PL used in Direct Combustion as obtained from solar tunnel drying and open sun drying are indicated in Table 1 below.

Table 1. Moisture contents of PLB from OSD and STD

\begin{tabular}{llllllll}
\hline Moisture content (wb) & \multicolumn{2}{l}{ Week } & \multicolumn{5}{c}{} \\
\hline & 4 & 5 & 6 & 4 & 5 & 6 \\
\cline { 2 - 7 } & OSD & & & \multicolumn{2}{c}{ STD } & \\
\cline { 2 - 7 } Initial (\%) & 59.2 & 60.4 & 62.3 & 59.2 & 60.4 & 62.3 \\
Final (\%) & 3.0 & 10.1 & 11.2 & 0.2 & 4.4 & 7.3 \\
\hline
\end{tabular}

The initial and final moisture contents obtained from open sun drying and solar tunnel drying from all week ages are presented in Table 1. From the table, it can be observed that as the weeks progress the moisture content increases. This may have been due to less composition of chicken manure in earlier weeks, disabling PLB at this age to hold less water, compared to more composition of chicken manure in the latter week enabling PLB at this age to hold more water. Manure tends to stick thus this gives the litter the ability of holding more moisture. Some of the reasons outlined by (Loch et al., 2011) are that moisture content in poultry litter may be due to the type of diet, water intake, environmental temperature, ventilation and, mainly, the type of drinker used. The effectiveness of the solar tunnel dryer is clearly seen as the final moisture is lower than that obtained under open sun drying. On average, the briquettes from all the weeks had an initial moisture content of $61 \%(\mathrm{wb})$ which yielded a distinctive final moisture content under the abovementioned drying methods. Briquettes from open sun drying had an average 
final moisture content of $8.1 \%$ (wb) compared to $4 \%$ (wb) from the solar tunnel dryer. This suggests that PLB samples in the solar tunnel dryer had a higher drying rate than those of open-sun drying due to the higher drying air temperature in the solar tunnel dryer as compared to ambient air temperature. According to Dávalos et al., (2002) complete combustion cannot be accomplished with litter of more than $9 \%$ but is only feasible with litter of less than $9 \%$ denoting that more moisture content reduces the combustibility of a fuel as also reported by Thyagarajan et al., (2013). Dalólio et al., (2017) also affirmed that moisture content is the main obstacle during the direct combustion of poultry litter. It was further stated that an evaluation of the direct combustion of poultry litter of an initial moisture content of $70.4 \%(\mathrm{wb})$ and final moisture content of less than $10 \%(\mathrm{wb})$ was carried out. Findings were that the litter with $9 \%$ moisture burnt directly while the wet samples experienced incomplete combustion causing a formation of carbon monoxide and higher pollutant emissions. As seen from Table 1, the final moisture contents compared well with the mentioned studies. The average initial moisture content (61\%) in this study also falls in the range of $80-20 \%$ (Baldin et al., 2012) and also close to that of $70.4 \%$ by (Dávalos et al., 2002).

\subsection{Direct Combustion (DC) and Heat Distribution (HD) of PLB}

Poultry litter briquettes across all week ages were directly combusted and the heat distribution was measured as shown in Figure 2.
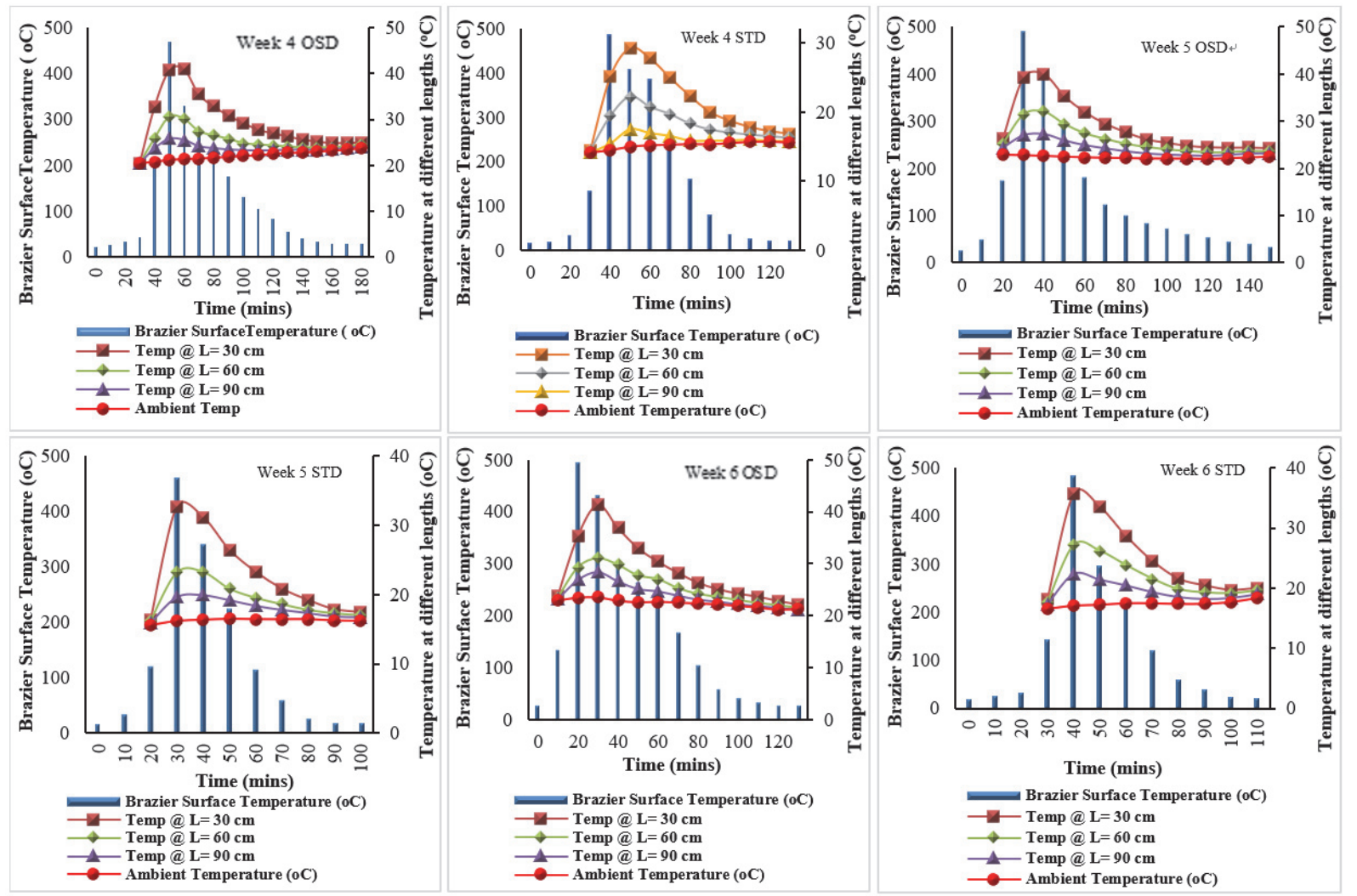

Figure 2. Heat distribution during DC of PLB at week 4, 5 and 6 from OSD and STD at different lengths

As observed from Figure 2, the brazier surface temperature $\left(\mathrm{B}_{\mathrm{ST}}\right)$ was rapidly falling but the temperature drop at different lengths was not as rapid because the surrounding air was still warm. Despite the different times of commencement of the experiments, the temperature difference at different lengths in relation to the ambient were more or less the same across all weeks. From week 4 during the combustion of PLB from OSD which started at $0933 \mathrm{hrs}$ and ended at $1233 \mathrm{hrs}$, the highest temperature of $40.5^{\circ} \mathrm{C}$ was recorded at a length of $30 \mathrm{~cm}$ at an ambient temperature of $21.1^{\circ} \mathrm{C}$. The difference between these temperatures was $19.4^{\circ} \mathrm{C}$. Similarly, DC at week 6 for PLB from OSD which started at $1515 \mathrm{hrs}$ and ended at $1740 \mathrm{hrs}$ had the highest temperature of $41.4^{\circ} \mathrm{C}$ at a length of $30 \mathrm{~cm}$ at an ambient temperature of $23.5^{\circ} \mathrm{C}$. The difference yielded between these temperatures was $17.9^{\circ} \mathrm{C}$ which was separated by only $1.5^{\circ} \mathrm{C}$ as compared to that from week 4 . The averages of $\mathrm{B}_{\mathrm{ST}}$ from week 4,5 and 6 were $480^{\circ} \mathrm{C}, 476^{\circ} \mathrm{C}$ and $489^{\circ} \mathrm{C}$ respectively, which were not that far apart indicating that they were more or less the same. A directly proportional relationship was depicted from the $\mathrm{B}_{\mathrm{ST}}$ and different chosen lengths as they both increased 
and dropped in a similar manner. The heat production and distribution also assumes the same behavior regardless of the drying method.

A high $\mathrm{B}_{\mathrm{ST}}$ of $471^{\circ} \mathrm{C}$ was produced for PLB at week 4 OSD at the $50^{\text {th }}$ minute which dropped until the $140^{\text {th }}$ minute. At $30 \mathrm{~cm}$ the highest temperature of $40.5^{\circ} \mathrm{C}$ was recorded and lasted for 10 minutes. At a length of $60 \mathrm{~cm}$ the highest temperature of $30.6^{\circ} \mathrm{C}$ was recorded and the air at this distance was heated to an increment of $9.5^{\circ} \mathrm{C}$ in relation to the ambient. Length of $90 \mathrm{~cm}$ had a peak temperature of $25.8^{\circ} \mathrm{C}$ yielding a temperature difference of $4.7^{\circ} \mathrm{C}$ with the ambient. Both lengths experienced continual temperature drop until the $180^{\text {th }}$ minute. DC for PLB from STD had peak $\mathrm{B}_{\text {ST }}$ of $489^{\circ} \mathrm{C}$. The peak was recorded at the $50^{\text {th }}$ minute and started to fall until the $120^{\text {th }}$ minute. DC at week $4 \mathrm{OSD}$ and STD were started at $0933 \mathrm{hrs}$ to $1233 \mathrm{hrs}$ and $0730 \mathrm{hrs}$ to $0940 \mathrm{hrs}$ respectively. Similarly, the temperature behavior of DC at week 5 trended as that at week 4 with $\mathrm{B}_{\mathrm{ST}}$ clearly constantly rising until $30^{\text {th }}$ minute where it started to drop. PLB for OSD produced high a temperature of $491^{\circ} \mathrm{C}$ at the $30^{\text {th }}$ minute which dropped until the $150^{\text {th }}$ minute. $\mathrm{B}_{\text {ST }}$ dropped to a final temperature of $24.3^{\circ} \mathrm{C}$ at the $150^{\text {th }}$ minute. $40^{\circ} \mathrm{C}$ was recorded at $30 \mathrm{~cm}$ which lasted for 10 minutes and started dropping until the $150^{\text {th }}$ minute.

At $60 \mathrm{~cm}$ a topmost temperature of $32^{\circ} \mathrm{C}$ was recorded which also lasted for 10 minutes and the air at this distance was heated to an increment of $9^{\circ} \mathrm{C}$ in relation to the ambient. Length of $90 \mathrm{~cm}$ had a higher temperature of $27.2^{\circ} \mathrm{C}$ hence only yielding a temperature difference of $4.2^{\circ} \mathrm{C}$. Both lengths experienced continual temperature drop until the $150^{\text {th }}$ minute. DC of PLB from OSD commenced from $1230 \mathrm{hrs}$ to $1500 \mathrm{hrs}$. $\mathrm{B}_{\mathrm{ST}}$ of $461^{\circ} \mathrm{C}$ was recorded during the DC of PLB from STD as a peak temperature. DC of PLB from STD was started from 1010hrs to 1130hrs. PLB from OSD in week 6 had the highest $\mathrm{B}_{\mathrm{ST}}$ of $493^{\circ} \mathrm{C}$ which was recorded at the $20^{\text {th }}$ minute then dropped to $26^{\circ} \mathrm{C}$ at the $120^{\text {th }}$ minute. A peak temperature of $41.4^{\circ} \mathrm{C}$ was recorded at $30 \mathrm{~cm}$. At $60 \mathrm{~cm}$ the uppermost temperature of $31^{\circ} \mathrm{C}$ was recorded and the air at this distance was heated to an increment of $7.5^{\circ} \mathrm{C}$ in relation to the ambient. A length of $90 \mathrm{~cm}$ had a higher temperature of $28.5^{\circ} \mathrm{C}$ yielding a temperature difference of $5^{\circ} \mathrm{C}$ with the ambient. Both lengths experienced continual temperature drop until the $130^{\text {th }}$ minute. DC of PLB from OSD commenced from $1515 \mathrm{hrs}$ to $1740 \mathrm{hrs}$. $\mathrm{B}_{\mathrm{ST}}$ of $485^{\circ} \mathrm{C}$ was recorded during the DC of PLB from STD as a peak temperature at the $40^{\text {th }}$ minute and dropped to $22^{\circ} \mathrm{C}$ at the $110^{\text {th }}$ minute. A highest temperature of $35.8^{\circ} \mathrm{C}$ was recorded and had a difference of $18.7^{\circ} \mathrm{C}$ in relation to the ambient at a length of $30 \mathrm{~cm}$. At a length of $60 \mathrm{~cm}$, a peak of $27.2^{\circ} \mathrm{C}$ was recorded and managing to heat the air at this length by $10.1^{\circ} \mathrm{C}$. At $90 \mathrm{~cm}$, a peak of $22.3^{\circ} \mathrm{C}$ was recorded thus heating the surrounding air by $5.2^{\circ} \mathrm{C}$. DC of PLB from STD was started from 1137hrs to $1326 \mathrm{hrs}$.

\section{$3.2 H_{D}$ of $D C$ of Charcoal}

The heat distribution of the direct combustion of charcoal is shown is Figure 3.

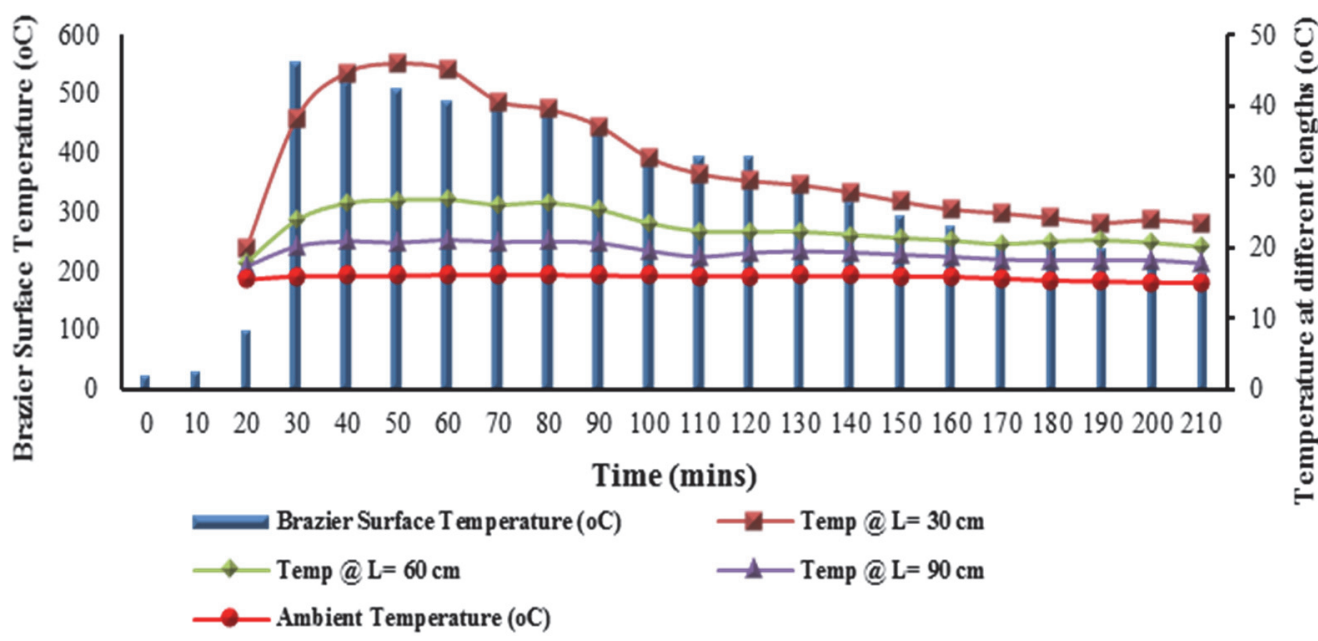

Figure 3. Heat distribution during DC of Charcoal at different lengths

Figure 3 shows the heat distribution during DC of charcoal. Initially, $\mathrm{B}_{\mathrm{ST}}$ had a temperature of $21^{\circ} \mathrm{C}$ which rose rapidly to highs of $555^{\circ} \mathrm{C}$ at the $30^{\text {th }}$ minute as seen in Figure 3. The temperature then dropped to $198^{\circ} \mathrm{C}$ at the $210^{\text {th }}$ minute. At $30 \mathrm{~cm}$, a peak temperature reading of $45.9^{\circ} \mathrm{C}$ was recorded remaining constant for 10 minutes then dropped. The ambient temperature was $16.2^{\circ} \mathrm{C}$ making the air temperature at $30 \mathrm{~cm}$ to rise to $29.7^{\circ} \mathrm{C}$. At 40 minutes, a length of $60 \mathrm{~cm}$ had a high temperature reading of $26.6^{\circ} \mathrm{C}$ which remained constant for 40 minutes then started 
dropping. A length of $90 \mathrm{~cm}$ had peak temperature readings of $20.9^{\circ} \mathrm{C}$ which also remained constant for 40 minutes. A length of $30 \mathrm{~cm}$ did not maintain its peak temperatures for long because it was closer to the brazier thus it was sensitive to any temperature change. The DC of charcoal started from $1800 \mathrm{hrs}$ to $2130 \mathrm{hrs}$. Charcoal had the highest temperatures during DC as compared to temperatures recorded from DC of PLB across all weeks.

\subsection{Comparison of $B_{S T}$ of DC of PLB from OSD and STD to Charcoal}

The plot of the temperature of the brazier surface measured from the combustion of PLB from all weeks for OSD and STD and Charcoal is shown in Figure 4.
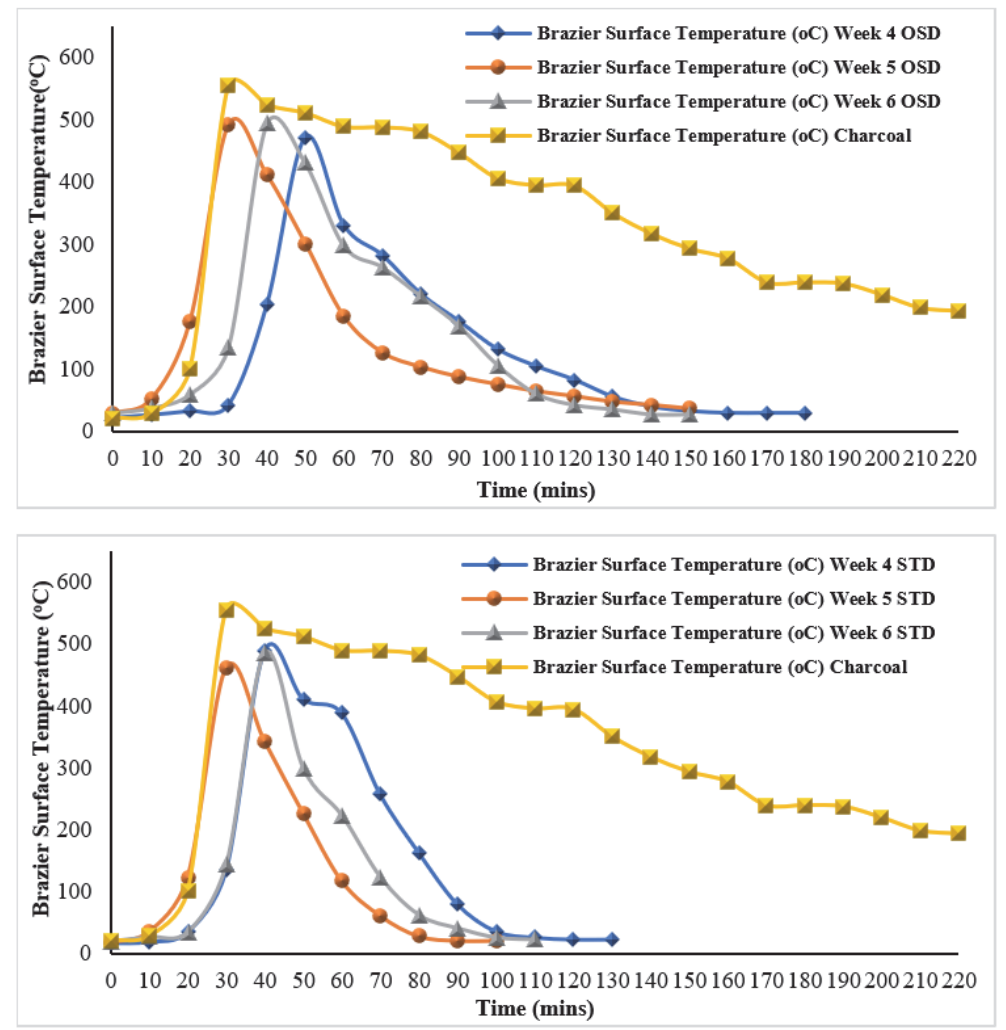

Figure 4. Comparing BST from DC of PLB from OSD and STD to Charcoal

From Figure 4 it can be clearly seen that charcoal burns longer than all PLB from all weeks. Charcoal was able to sustain high temperatures for at most 80 minutes. A peak of $555^{\circ} \mathrm{C}$ was recorded on the surface of the brazier at 30 minutes which then slightly dropped to $524^{\circ} \mathrm{C}$. The temperature further dropped and recorded a temperature of $406^{\circ} \mathrm{C}$ at the $100^{\text {th }}$ minute. Charcoal is a carbonized material with significant amounts of fixed carbon thus making it burn longer than PLB. The remnant carbon in the material after volatile materials are driven off is known as fixed carbon, of which belonging to charcoal ranges from $50 \%$ to $95 \%$ (Raju et al., 2014). According to Falemara et al., (2018), a low ash content images a high CV indicating that a material does not contain non-combustible matters. It was further reported that the combustion remnant is increased by ash content thus causing a decrease in the heating effect. As seen from Figure 5 charcoal had the lowest ash content of $8.4 \%$ which may have been one other reason why it produced more heat than PLB and for a longer period of time. Charcoal stood the test of time because even after the burn out of PLB at about 130 minutes, higher temperatures of $350^{\circ} \mathrm{C}$ were still being recorded. On average, PLB was able to produce suitable temperatures at lengths of $30 \mathrm{~cm}$ and $60 \mathrm{~cm}$ for $90-100$ minutes while charcoal had the longest suitable heat distribution of 140-180 minutes.

\subsection{Statistical Analysis BST of Charcoal and PLB}

Statistical Package for Social Sciences (SPSS) was used to determine the difference between the produced heat from Charcoal and PLB. LSD under multiple comparisons was used to carry out this test at the significance level of 0.05 . The results are presented in Table 2 . 
Table 2. LSD Multiple Comparisons $B_{\text {ST }}$ of charcoal and PLB OSD and STD

\begin{tabular}{|c|c|c|c|c|}
\hline (I) $\mathrm{B}_{\mathrm{ST}}$ & (J)B $B_{\mathrm{ST}}$ & Mean Difference (I-J) & Std. Error & Sig. \\
\hline \multirow[t]{6}{*}{$\mathrm{B}_{\mathrm{ST}}$ Charcoal } & $\mathrm{B}_{\mathrm{ST}} \mathrm{W} 4 \mathrm{OSD}$ & 198.98787 & 45.94165 & 0.00003 \\
\hline & $\mathrm{B}_{\mathrm{ST}} \mathrm{W} 4 \mathrm{STD}$ & 171.71118 & 50.23374 & 0.00090 \\
\hline & $\mathrm{B}_{\mathrm{ST}} \mathrm{W} 5$ OSD & 179.34511 & 48.24263 & 0.00033 \\
\hline & $\mathrm{B}_{\mathrm{ST}} \mathrm{W} 5 \mathrm{STD}$ & 189.60079 & 54.32526 & 0.00071 \\
\hline & $\mathrm{B}_{\mathrm{ST}} \mathrm{W6}$ OSD & 170.97011 & 48.24263 & 0.00059 \\
\hline & $\mathrm{B}_{\mathrm{ST}} \mathrm{W} 6 \mathrm{STD}$ & 197.03261 & 52.77182 & 0.00031 \\
\hline \multirow{6}{*}{$\mathrm{B}_{\mathrm{ST}} \mathrm{W} 4 \mathrm{OSD}$} & $\mathrm{B}_{\mathrm{ST}}$ Charcoal & -198.98787 & 45.94165 & 0.00003 \\
\hline & $\mathrm{B}_{\mathrm{ST}} \mathrm{W} 4 \mathrm{STD}$ & -27.27669 & 52.19619 & 0.60238 \\
\hline & $\mathrm{B}_{\mathrm{ST}} \mathrm{W} 5$ OSD & -19.64276 & 50.28285 & 0.69686 \\
\hline & $\mathrm{B}_{\mathrm{ST}} \mathrm{W} 5 \mathrm{STD}$ & -9.38708 & 56.14487 & 0.86754 \\
\hline & $\mathrm{B}_{\mathrm{ST}} \mathrm{W} 6$ OSD & -28.01776 & 50.28285 & 0.57859 \\
\hline & $\mathrm{B}_{\mathrm{ST}} \mathrm{W} 6 \mathrm{STD}$ & -1.95526 & 54.64319 & 0.97152 \\
\hline \multirow{6}{*}{$\mathrm{B}_{\mathrm{ST}} \mathrm{W} 4 \mathrm{STD}$} & $\mathrm{B}_{\mathrm{ST}}$ Charcoal & -171.71118 & 50.23374 & 0.00090 \\
\hline & $\mathrm{B}_{\mathrm{ST}} \mathrm{W} 4 \mathrm{OSD}$ & 27.27669 & 52.19619 & 0.60238 \\
\hline & $\mathrm{B}_{\mathrm{ST}} \mathrm{W} 5$ OSD & 7.63393 & 54.23245 & 0.88833 \\
\hline & $\mathrm{B}_{\mathrm{ST}} \mathrm{W} 5$ STD & 17.88961 & 59.70796 & 0.76507 \\
\hline & $\mathrm{B}_{\mathrm{ST}} \mathrm{W} 6$ OSD & -0.74107 & 54.23245 & 0.98912 \\
\hline & $\mathrm{B}_{\mathrm{ST}} \mathrm{W} 6 \mathrm{STD}$ & 25.32143 & 58.29813 & 0.66494 \\
\hline \multirow{6}{*}{$\mathrm{B}_{\mathrm{ST}} \mathrm{W} 5$ OSD } & $\mathrm{B}_{\mathrm{ST}}$ Charcoal & -179.34511 & 48.24263 & 0.00033 \\
\hline & $\mathrm{B}_{\mathrm{ST}} \mathrm{W} 4 \mathrm{OSD}$ & 19.64276 & 50.28285 & 0.69686 \\
\hline & $\mathrm{B}_{\mathrm{ST}} \mathrm{W} 4 \mathrm{STD}$ & -7.63393 & 54.23245 & 0.88833 \\
\hline & $\mathrm{B}_{\mathrm{ST}} \mathrm{W} 5 \mathrm{STD}$ & 10.25568 & 58.04278 & 0.86009 \\
\hline & $\mathrm{B}_{\mathrm{ST}} \mathrm{W} 6$ OSD & -8.37500 & 52.39353 & 0.87331 \\
\hline & $\mathrm{B}_{\mathrm{ST}} \mathrm{W} 6 \mathrm{STD}$ & 17.68750 & 56.59148 & 0.75525 \\
\hline \multirow[t]{6}{*}{$\mathrm{B}_{\mathrm{ST}} \mathrm{W} 5 \mathrm{STD}$} & $\mathrm{B}_{\mathrm{ST}}$ Charcoal & -189.60079 & 54.32526 & 0.00071 \\
\hline & $\mathrm{B}_{\mathrm{ST}} \mathrm{W} 4 \mathrm{OSD}$ & 9.38708 & 56.14487 & 0.86754 \\
\hline & $\mathrm{B}_{\mathrm{ST}} \mathrm{W} 4 \mathrm{STD}$ & -17.88961 & 59.70796 & 0.76507 \\
\hline & $\mathrm{B}_{\mathrm{ST}} \mathrm{W} 5$ OSD & -10.25568 & 58.04278 & 0.86009 \\
\hline & $\mathrm{B}_{\mathrm{ST}} \mathrm{W} 6$ OSD & -18.63068 & 58.04278 & 0.74887 \\
\hline & $\mathrm{B}_{\mathrm{ST}} \mathrm{W} 6 \mathrm{STD}$ & 7.43182 & 61.85853 & 0.90460 \\
\hline \multirow[t]{6}{*}{$\mathrm{B}_{\mathrm{ST}} \mathrm{W} 6$ OSD } & $\mathrm{B}_{\mathrm{ST}}$ Charcoal & -170.97011 & 48.24263 & 0.00059 \\
\hline & $\mathrm{B}_{\mathrm{ST}} \mathrm{W} 4 \mathrm{OSD}$ & 28.01776 & 50.28285 & 0.57859 \\
\hline & $\mathrm{B}_{\mathrm{ST}} \mathrm{W} 4 \mathrm{STD}$ & 0.74107 & 54.23245 & 0.98912 \\
\hline & $\mathrm{B}_{\mathrm{ST}} \mathrm{W} 5$ OSD & 8.37500 & 52.39353 & 0.87331 \\
\hline & $\mathrm{B}_{\mathrm{ST}} \mathrm{W} 5 \mathrm{STD}$ & 18.63068 & 58.04278 & 0.74887 \\
\hline & $\mathrm{B}_{\mathrm{ST}} \mathrm{W} 6 \mathrm{STD}$ & 26.06250 & 56.59148 & 0.64609 \\
\hline \multirow[t]{6}{*}{$\mathrm{B}_{\mathrm{ST}} \mathrm{W} 6 \mathrm{STD}$} & $\mathrm{B}_{\mathrm{ST}}$ Charcoal & -197.03261 & 52.77182 & 0.00031 \\
\hline & $\mathrm{B}_{\mathrm{ST}} \mathrm{W} 4 \mathrm{OSD}$ & 1.95526 & 54.64319 & 0.97152 \\
\hline & $\mathrm{B}_{\mathrm{ST}} \mathrm{W} 4 \mathrm{STD}$ & -25.32143 & 58.29813 & 0.66494 \\
\hline & $\mathrm{B}_{\mathrm{ST}} \mathrm{W} 5$ OSD & -17.68750 & 56.59148 & 0.75525 \\
\hline & $\mathrm{B}_{\mathrm{ST}} \mathrm{W} 5 \mathrm{STD}$ & -7.43182 & 61.85853 & 0.90460 \\
\hline & $\mathrm{B}_{\mathrm{ST}} \mathrm{W} 6$ OSD & -26.06250 & 56.59148 & 0.64609 \\
\hline
\end{tabular}

Based on observed means. The error term is Mean Square (Error) $=21960.653$

*. The mean difference is significant at the 0.05 level

From Table 2 the nature of variation is clearly seen. Comparisons starts with $\mathrm{B}_{\mathrm{ST}}$ of charcoal to other treatments. The obtained values for the probability of this comparison being similar were 0.00003, 0.00090, 0.00033, 0.00071, 0.00059 and 0.00031 belonging to $\mathrm{B}_{\mathrm{ST}}$ week 4 OSD, B $\mathrm{ST}_{\mathrm{ST}}$ week $4 \mathrm{STD}$, B $\mathrm{ST}_{\mathrm{ST}}$ week 5 OSD, B $\mathrm{ST}_{\mathrm{ST}}$ week 5 STD, B week 6 OSD and $\mathrm{B}_{\mathrm{ST}}$ week 6 STD respectively. The values attained are less than the significance level of 0.05 meaning that there is a significant difference between temperatures from the combustion of charcoal as compared to the combustion of PLB at all weeks from either method of drying. This means that charcoal produces more heat than PLB regardless of the PL age as can be seen from Figure 4. The subsequent comparison was that of week 4 OSD to all other treatments. The resulting P-values were $0.60238,0.69686,0.86754,0.57859,0.97152$ for $\mathrm{B}_{\mathrm{ST}}$ 


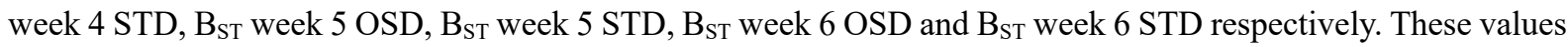
are all greater than the significance level of 0.05 meaning that there is no significant difference between the temperatures produced by PLB at week 4 OSD and other PLB from the remaining weeks from either method of drying, thus the produced temperatures were the same. Correspondingly, PLB from all the remaining weeks were compared amongst each other and gave the lowest P-value of 0.57859 and the highest of 0.98912 giving a revelation that there is a 58\% - 99\% chance that the heat acquired from PLB at any age and drying method can be the same. Therefore, there is no significant difference between PLB B B at any age and drying method at a significance level of $0.05 \%$. This is true because heat produced from PLB ranged from $461^{\circ} \mathrm{C}$ to $493^{\circ} \mathrm{C}$ which are not that far apart.

\subsection{Ash Content}

Important information regarding PL quality is provided by the ash content since it measures the mineral content of the litter. Ash content comparisons of charcoal and PLB at different ages of weeks is shown in Figure 5.

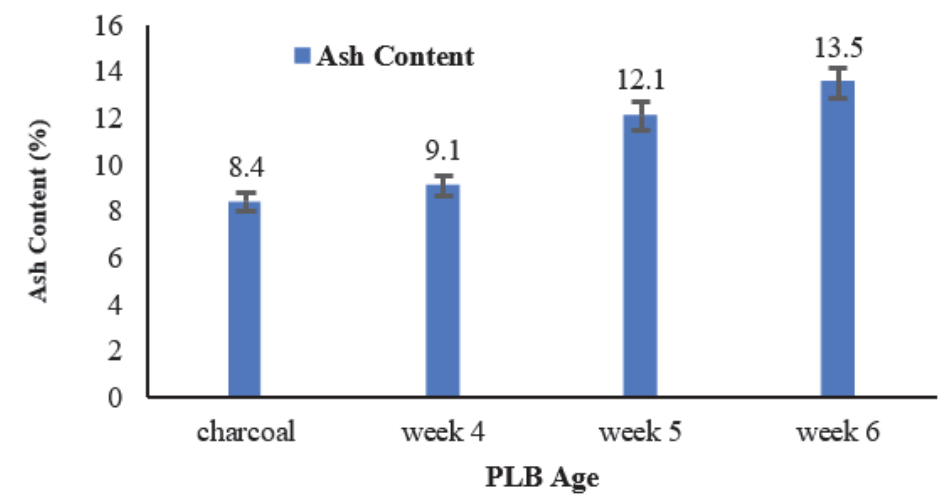

Figure 5. Ash content in percentage of the charcoal and PLB at different weeks

It is apparent that as PL ages according to weeks, the ash content increases. PLB at week 4 as seen in Figure 5 had the lowest ash content of $9.1 \%$ followed by week 5 with $12.1 \%$ and week 6 being the highest with ash content of 13.5\%. Babatope et al., (2012) obtained results which showed that broiler litter pellets contained more ash than layer litter. Broiler litter had an ash content ranging from 13.27 to $14.17 \%$ while layers had a range of 12.65 to $13.60 \%$. Acharya et al., (2014) also acquired results which yielded the ash content of $11.5 \%$ for broilers. The broiler litter obtained in the current study had the ash content within this range. The quantity of manure in the litter increases with the growth of chickens and when the litter is combusted more ashes will be produced since there will be more organic matter to burn and less of the wood shavings. In line with this, Rico-contreras et al., (2017) reported that the ash content in poultry litter depends on the organic matter available for combustion. Also, Babatope et al., (2012) pinpointed that poultry litter normally has high ash content because of the amount of dirt contamination which has occurred in the litter. Charcoal was used as a control and it had a low ash content of $8.4 \%$ which was almost similar to that obtained at week 4 . The ash content of charcoal was around the value found by Koyuncu and Pinar, (2007) which was 5.86\%.

\subsection{Calorific Value (CV) Determination of PLB}

The Calorific Values of PLB and Charcoal are shown in Table 3 below.

Table 3. Comparison of CV from Charcoal and PLB from week 4 OSD and week 6 STD

\begin{tabular}{ll}
\hline Biomass & Calorific Value (CV-MJ/kg) \\
\hline PLB Week 4 OSD & 15.65 \\
PLB Week 6 STD & 14.57 \\
Charcoal & 30.8 \\
\hline
\end{tabular}

Two samples of PLB at week 4 OSD and week 6 STD were used to represent all other PLB for CV experiments since they were a week apart. Table 2 shows that there is more or less of a similarity between $\mathrm{CV}$ from week 4 and week 6. Week 4 had a gross CV of $15.65 \mathrm{MJ} / \mathrm{kg}$ while at week 6 the $\mathrm{CV}$ was $14.57 \mathrm{MJ} / \mathrm{kg}$. The slight drop of CV at 
week 6 STD may have been due to the decomposition of essential elements needed to enhance combustion. Also, since the ash content was increasing with number of weeks, this might have led to a minor diminish in the CV obtained at week 6 since more ash reduces the heating value of a material. The CV of PLB obtained from this study is not very different from the one acquired by Abelha et al., (2003) of $13.5 \mathrm{MJ} / \mathrm{kg}$ under a research on combustion of poultry litter in a fluidized bed combustor. A CV of $30.8 \mathrm{MJ} / \mathrm{kg}$ was obtained from Sánchez et al., (2014) which was chosen to represent charcoal CV in this study. Both CV of PLB of the samples tested were lower than that of charcoal. They were about half of charcoal CV. Charcoal has high carbon and hydrogen content compared to PLB since it has been thermally treated by pyrolysis. According to Raju et al., (2014), an increase in carbon and hydrogen content results in an increase in CV. Also, the fixed carbon of charcoal was reported to range from $50 \%$ to $90 \%$. Hence charcoal produces more heat than PLB as seen from the CV.

\section{Conclusion}

Space heating of poultry houses can be carried out through the direct combustion of poultry litter. However, increments in the moisture content of the litter causes a decrease in the heat produced. In this study it was found out that PLB with a moisture content less than $12 \%$ could burn completely making these samples suitable for their use as fuel for heat generation through direct combustion.

PLB has lower volatiles, fixed carbon, higher nitrogen and ash content than charcoal thus less heat was produced from PLB as compared to charcoal. PLB generally produced sufficient heat for a maximum of 100 minutes whereas charcoal was able to burn for a maximum of 180 minutes.

A distance of $30 \mathrm{~cm}$ from the brazier showed a positive response on heat distribution since temperatures were sustained in the range of $22^{\circ} \mathrm{C}$ to $32^{\circ} \mathrm{C}$ (suitable for chicks), thus it can be an effective distance to provide comfort to chicks during cold temperatures. The distance of $60 \mathrm{~cm}$ was as well effective unlike that of $90 \mathrm{~cm}$ which gave low air temperatures.

Generally, as seen from the CV obtained and heat produced from PLB, the age of PL does not affect the CV or heat produced by the PLB, thus PL at any age can be used for making briquettes. But using PL at an early age (week 4) will require more binder which will be costlier as compared to the binder requirement at week 6 .

The ash content of PLB increased as weeks lapsed and this causes concern of the disposal of the ash as well as affecting the $\mathrm{CV}$ of the briquettes by reducing it. In spite of this, acquiring PL at week 4 contributes to costs incurred since the bedding will have to be replaced, hence it is better to get the final product which is regarded to as a waste.

The results obtained from PLB dried from STD and OSD showed no significant difference in terms of CV, heat distribution and the $\mathrm{B}_{\mathrm{ST}}$ since they were all dried to the same final mass.

The utilization of these briquettes can help to mitigate concerns over; deforestation and its outcomes, agricultural and wood wastes management issues as well as contamination problems. Enhancements on job opportunities, market diversification and rural economic empowerment can also be accomplished.

Since the ash acquired from this study was not used to any extent, fertilizer requirements which are crop specific can be determined in-order to have full understanding of how much ash is needed to be applied to the receiving crop to minimize nutrient leaching. Studies have been carried out which states the composition of the litter ash and that it can be used as a fertilizer. Also, as a mitigation measure aimed towards the observed smoke, a study on different binder ratios and an equipment which can induce more compression force can be experimented on.

\section{Acknowledgement}

The authors wish to acknowledge the funding from the European Commission through the METEGA-Intra-ACP Academic Mobility Scheme for rendering this research possible.

\section{References}

Abelha, P., Gulyurtlu, I., Boavida, D., Barros, J. S., \& Cabrita, I. (2003). Combustion of Poultry Litter in a Fluidised Bed Combustor. Fuel, 82, 687-692. Retrieved from http://www.fuelfirst.com

Acar, S., \& Ayanoglu, A. (2012). Determination of Higher Heating Values ( HHVs ) of Biomass Fuels', Energy Education Science and Technology Part A: Energy Science and Research, 28(2), 749-758. Retrieved from https://www.researchgate.net/publication/283743694

Acharya, B., Dutta, A., Mahmud, S., Tushar, M., \& Leon, M. (2014). Ash Analysis of Poultry Litter, Willow and Oats for Combustion in Boilers. Journal of Biomass to Biofuel, 1, 16-26. https://doi.org/10.11159/jbb.2014.003 
Altun, N. E., Hicyilmaz, C., \& Bagci, A. S. (2004). Influence of Coal Briquette Size on the Combustion Kinetics. Fuel Processing Technology, 85, 1345-1357. https://doi.org/10.1016/j.fuproc.2003.09.010

Andrew, C. M. (2011). The Effect of Moringa Supplementation on Growth and Health of Indigenous Zambian Chickens, MSc Thesis. University of Zambia.

Babatope, A., John, J. M., \& Farouk, F. (2012). Proximate Composition and Post-Production Stability of Poultry Waste Fertilizer Pellets. International Journal of Applied Biological Research, 4(1\&2), 25-31.

Baldin, V., Frozza, J. F., \& Lafay, J. S. (2012). Poultry litter : Great Potential for Electrical Energy Generation in Brazil. European Association for the Development of Renewable Energies, Environment and Power Quality (EA4EPQ), 1(10), 1058-1063. https://doi.org/10.24084/repqj10.580

Bogush, A., Anna, A., Julia, S., Richard, W., \& Wood, G. I. (2018). Element speciation in UK biomass power plant residues based on composition, mineralogy. microstructure and leaching Medium acid. Fuel. Elsevier, 211, 712-725. https://doi.org/10.1016/j.fuel.2017.09.103

Bolan, N. S., Szogi, A. A., Chuasavathi, T., Seshadri, B., Rothrock, M. J., \& Panneerselvam, P. (2017). Uses and management of poultry litter. 66(December 2010), 673-698. https://doi.org/10.1017/S0043933910000656.

Bouabid, G., Wassate, B., Touaj, K., Nahya, D., El Falaki, K., \& Azzi, M. (2015). Effluents Treatment Plants Sludge Characterization in Order to be Used as Solid Fuels', Materials and Environmental Science, 5(5), 1583-1590. Retrieved from https://www.researchgate.net/publication/276268151

Butcher, G. D., \& Miles, R. D. (2015). Causes and Prevention of Wet Litter in Broiler Houses, Report VM99. Gainesville. Retrieved from http://edis.ifas.ufl.edu

Dalólio, F. S., Jadir, N., Angélica, C., Carneiro, De O., Ilda, De, Fátima, F., Rúben, C., Michael, De O., Fernando T., \& Suani, T. (2017). Poultry Litter as Biomass Energy : A review and Future Perspectives. Renewable and Sustainable Energy Reviews. Elsevier Ltd, 76, 941-949. https://doi.org/10.1016/j.rser.2017.03.104

Dávalos, J. Z., Roux, V., \& Jiménez, P. (2002). Evaluation of Poultry Litter as a Feasible Fuel. Thermochimica Acta, 394, 261-266. Retrieved from http://www.elsevier.com/locate/tea

Demirbas, A. (2004). Combustion characteristics of different biomass fuels. Progress in Energy and Combustion Science, 30, 219-230. https://doi.org/10.1016/j.pecs.2003.10.004

Falemara, B. C., Victoria, I. J., Oluwaseyi, O. A., \& Rivi, D. N. (2018). Performance Evaluation of the Physical and Combustion Properties of Briquettes Produced from Agro-Wastes and Wood Residues. Recycling, 3(37), 1-14. https://doi.org/10.3390/recycling3030037

Jini, D., Kaushik, B., Rupankar, B., \& Deep, J. R. (2015). Identification of Critical Periods Environmentally Sensitive to Normal Performance of Vanaraja Poultry Breed in Climatically Different Locations. International Letters of Natural Sciences, 46, 76-83. https://doi.org/10.18052/www.scipress.com/ILNS.46.76

Kelleher, B. P., Leahy, J. J., Henihan, A. M., O’Dwyer, T. F., Sutton, D., \& Leahy, M. J. (2002). Advances in poultry litter disposal technology - A review. Bioresource Technology, 83, 27-36. Retrieved from http://www.elsevier.com

Koyuncu, T. Ã., \& Pinar, Y. (2007). The Emissions From a Space-heating Biomass Stove. Biomass and Bioenergy, 31, 73-79. https://doi.org/10.1016/j.biombioe.2006.06.014

Loch, F. C., Oliveira, M. C. De, Silva, D., Nunes, B., Faria, B. F. De, \& Menezes, J. F. S. (2011). Quality of Poultry Litter Submitted to Different Treatments in Five Consecutive Flocks', Revista Brasileira de Zootecnia, 40(5), 1025-1030. Retrieved from http://www.scielo.br/pdf/rbz/v40n5/a12v40n5.pdf

Matakala, P. W., Kokwe, M., \& Statz, J. (2015) Zambia National Strategy To Reduce Emissions From Deforestation And Forest Degradation (REDD+).

Molefe, M. J., \& Simate, I. N. (2019). Thin Layer Drying and Modelling of Poultry Litter Briquettes. Energy and Environment Research, 9(1), 9-17. https://doi.org/10.5539/eer.v9n1p9

Musa, W. et al. (2012). Poultry Litter Selection Management and Utilization in Nigeria. Asian Journal of Poultry Science, 6(2), 44-55. https://doi.org/10.3923/ajpsaj.2012.44.55

Nabangi, S. M. (2015). Temperature Profiles In A Foor Heated Brooder, Thesis-Master Of Science Energy Management. University Of Nairobi.

Raju, Ch. A. I., Satya, M., Praveena, U., \& Ramya, J. K. (2014). Studies On Development Of Fuel Briquettes Using Locally Avaliable Waste. International Journal of Engineering Research and Applications, 4(3), 553- 
559. Retrieved from http://www.ijera.com

Rico-contreras, O., Alberto, A. A., Gabriela, C., Juan, M. M., \& Jhony, J. L. (2017). Moisture Content Prediction in Poultry Litter Using Artificial Intelligence Techniques and Monte Carlo Simulation to Determine the Economic Yield from Energy Use. Journal of Environmental Management, 202, 254-267. https://doi.org/10.1016/j.jenvman.2017.07.034

Samboko, P., Antony, C., Auckland, K., Stephen, K., Rhoda, M., Bruno, M., \& Eustensia, M. (2016). The Impact of Power Rationing on Zambia's Agricultural Sector, Working Paper No. 105. Lusaka. Retrieved from http://www.aec.msu.edu/agecon/fs2/zambia/index.html

Sánchez, E. A., Pasache, M. B., \& García, M. E. (2014). Development of Briquettes from Waste Wood (Sawdust) for Use in Low-income Households. in Proceedings of the World Congress on Engineering 2014 Vol II, WCE 2014, July 2-4, 2014, London, U.K. London: IAENG, 1-6.

Teixeira, S. R., Pena, A. F. V., \& Miguel, A. G. (2010). Briquetting of charcoal from sugar-cane bagasse fly ash (scbfa) as an alternative fuel. Waste Management. Elsevier Ltd, 30, 804-807. https://doi.org/10.1016/j.wasman.2010.01.018

Tembo, S. T., Mulenga, B. P., \& Sitko, N. (2015). Cooking Fuel Choice in Urban Zambia : Implications on Forest Cover, Working Paper No. 94. 94. Lusaka, Zambia. Retrieved from http://www.aec.msu.edu/fs2/zambia/index.htm

Thyagarajan, D., Barathi, M., \& Sakthivadivu, R. (2013). Scope of Poultry Waste Utilization. Journal of Agriculture and Veterinary Science (IOSR-JAVS), 6(5), 29-35. Retrieved from http://www.iosrjournals.org

Weidemann, S. G., Bielefeld, E. N., McGahan, E. J., Valentine, J. G., \& Murphy. C. M. (2015). Grower Options for spent Litter Utilisation, Report-RIRDC Publication No. 14/093. Kingston. Retrieved from http://www.rirdc.gov.au

Williams, C. M. (2008). Poultry Waste Management in Developing Countries, FAO. North Carolina.

Zanaty, H. (2015). A Techno-Economic Study for Heating Poultry Houses Using Renewable Energy, Master of Science in Mechanical Engineering. The American University in Cairo School of Sciences and Engineering. https://doi.org/10.1.1.843.2738\&rep=rep1\&type=pdf

Zhang, G., Sun, Y., \& Xu, Y. (2018). Review of Briquette Binders and Briquetting Mechanism. Renewable and Sustainable Energy Reviews, Elsevier Ltd, 82, 477-487. https://doi.org/10.1016/j.rser.2017.09.072

\section{Copyrights}

Copyright for this article is retained by the author(s), with first publication rights granted to the journal.

This is an open-access article distributed under the terms and conditions of the Creative Commons Attribution license (http://creativecommons.org/licenses/by/4.0/). 